\title{
PENGARUH PENAMBAHAN AIR TERHADAP KUAT GESER DAN DAYA DUKUNG TANAH LEMPUNG
}

\author{
Ditha Kurnia ${ }^{1}$, Fatma Sarie ${ }^{2}$ dan Suradji gandi ${ }^{3}$ \\ ${ }^{123}$ Program Studi Teknik Sipil, Fakultas Teknik, Universitas Palangka Raya \\ E-mail: adittekniksipil@gmail.com¹, fatmasarie@jts.upr.ac.id², \\ suradjigandi_ir@jts.upr.ac.id ${ }^{3}$
}

\begin{abstract}
ABSTRAK
Semua beban konstruksi seperti jalan dan gedung diteruskan ke dalam tanah, sehingga kuat daya dukung tanah sangat berperan penting untuk mendirikan sebuah konstruksi diatasnya. Tujuan dari penelitian ini adalah untuk mengetahui pengaruh penggunaan air terhadap kuat geser dan daya dukung tanah lempung. Dalam penelitian ini menggunakan metode eksperimental, dan analitikal. Dari hasil pengujian kuat geser langsung (Direct Shear) terhadap nilai kuat geser dan daya dukung tanah asli yang dikeringkan 6 jam didapat nilai kuat geser $(\tau)$ tertinggi $0,288 \mathrm{~kg} / \mathrm{cm}^{2}$, sudut geser $25^{\circ}$, kohesi (c) $0,230 \mathrm{~kg} / \mathrm{cm}^{2}$, dengan persentase sebesar $13,83 \%$ sedangkan untuk nilai daya dukung tanah didapat nilai $\mathrm{q}_{\text {ult }}=6,94 \mathrm{~kg} / \mathrm{cm}^{2}$, dan nilai $\mathrm{q}_{\mathrm{ijin}}=2,31 \mathrm{~kg} / \mathrm{cm}^{2}$. Setelah penambahan pada campuran tanah asli $+5 \%$ air didapat nilai kuat geser $(\tau)$ sebesar $0,198 \mathrm{~kg} / \mathrm{cm}^{2}$, sudut geser $19^{\circ}$, kohesi (c) $0,150 \mathrm{~kg} / \mathrm{cm}^{2}$ sedangkan untuk nilai daya dukung tanah didapat nilai $\mathrm{q}_{\mathrm{ult}}=3,64 \mathrm{~kg} / \mathrm{cm}^{2}$, dan nilai $\mathrm{q}_{\mathrm{ijin}}=1,21 \mathrm{~kg} / \mathrm{cm}^{2}$. Sehingga dapat disimpulkan bahwa dengan penambahan air memberikan pengaruh terhadap nilai kuat geser dan daya dukung pada tanah lempung.
\end{abstract}

\section{Kata Kunci: Kuat Geser, Daya Dukung, Tanah Lempung}

\begin{abstract}
All construction loads such as roads and buildings are passed into the ground, so that the strong bearing capacity of the soil plays an important role in establishing a construction on it. The purpose of this study was to determine the effect of water use on the shear strength and bearing capacity of clay soil. In this study using experimental and analytical methods. From the results of direct shear strength testing on the value of shear strength and bearing capacity of the original soil that was dried for 6 hours, the highest value of shear strength $(\tau)$ was $0.288 \mathrm{~kg} / \mathrm{cm} 2$, shear angle $25^{\circ}$, cohesion (c) $0.230 \mathrm{~kg} / \mathrm{cm} 2$, with a percentage of $13.83 \%$ while for the value of the bearing capacity of the soil the value of qult $=6.94 \mathrm{~kg} / \mathrm{cm} 2$, and the value of qijin $=2.31 \mathrm{~kg} / \mathrm{cm} 2$. After adding to the original soil mixture $+5 \%$ water, the value of shear strength $(\tau)$ is 0.198 $\mathrm{kg} / \mathrm{cm} 2$, shear angle is $19^{\circ}$, cohesion (c) is $0.150 \mathrm{~kg} / \mathrm{cm} 2$, while for the value of the bearing capacity of the soil, the value of qult $=3.64 \mathrm{~kg}$ is obtained. $/ \mathrm{cm} 2$, and the value of qijin $=1.21 \mathrm{~kg} / \mathrm{cm} 2$. So it can be concluded that the addition of water has an effect on the value of the shear strength and bearing capacity of the clay soil.
\end{abstract}

Key Word: Shear Strength, Bearing Capacity, Clay

\section{Latar Belakang}

\section{PENDAHULUAN}

Tanah lempung adalah tanah yang mempunyai partikel-partikel tertentu yang menghasilkan sifat-sifat plastisitas pada tanah bila di campur dengan air. Tanah lempung dengan plastisitas tinggi, kohesifitas yang besar berakibat fluktuasi kembang 
susut yang relatif besar. Kondisi tanah basah volume tanah akan mengembang sehingga kuat gesernya akan rendah dan tanah akan lengket, sedangkan pada kondisi kering akan mengalami retakan-retakan akibat tegangan susut dan tanah dalam kondisi keras. Selain itu tanah lempung mempunyai volume pori yang besar sehingga mempunyai berat isi dan sudut gesek yang kecil. Tanah lempung merupakan partikel mineral yang berukuran lebih kecil dari 0,002 mm. (Bowles, 1991).

Namun dalam beberapa kasus sering ditemui tanah yang tidak layak sebagai tanah dasar dari suatu bangunan badan jalan atau konstruksi yang berada diatasnya, sehingga sangat sulit untuk mendirikan sebuah bangunan pada tanah yang memiliki daya dukung rendah. Tanah juga merupakan material konstruksi paling dasar sebagai tempat berdirinya suatu konstruksi. Dalam penelitian ini sampel tanah yang digunakan dari Kelurahan Petuk Katimpun KM.10 Kecamatan Jekan Raya Kota Palangka Raya Provinsi Kalimantan Tengah. Salah satu permasalahan dilokasi yaitu perilaku tanah yang tidak stabil karena pengaruh jalan sering terendam air sehingga terjadi penurunan pada tanah yang membuat jalan tidak rata atau bergelombang dan berlobang.

\section{Tujuan Penelitian}

Tujuan dari penelitian ini adalah mengetahui pengaruh penggunaan air terhadap kuat geser dan daya dukung tanah lempung pada Kel. Petuk Katimpun KM.10 Kec. Jekan Raya Kota Palangka Raya Provinsi Kalimantan Tengah.

\section{TINJAUAN PUSTAKA}

\section{Tanah}

Menurut (Das, 1995), tanah adalah material yang terdiri dari agregat atau butiran mineral-mineral padat yang tidak tersementasi (terikat secara kimia) satu sama lain dari bahan organik yang telah melapuk (yang berpartikel padat) disertai zat cair juga gas yang mengisi ruang-ruang kosong diantara partikel-partikel padat tersebut.

\section{Sistem Klasifikasi Tanah}

Sistem klasifikasi tanah adalah sistem yang menjelaskan secara singkat sifat-sifat umum tanah yang sangat bervariasi kedalam bentuk tabel dan grafik. Sistem klasifikasi yang digunakan dalam penelitian ini adalah sistem klasifikasi AASHTO (American Association of State Highway and Transportation Official) dan sistem klasifikasi USCS (Unified Soil Classification System).

Sistem klasifikasi AASHTO didasarkan pada kriteria atau klasifikasi umum yaitu:

1. Analisis saringan dengan persentase lolos saringan No. 200

2. Sifat fraksi yang lolos saringan No. 40 yaitu nilai dari batas cair dan indeks plastisitas

Adapun sistem klasifikasi USCS didasarkan pada kriteria atau klasifikasi yaitu:

1. Analisis saringan dengan presentase lolos saringan No. 200

2. Sifat fraksi yang lolos saringan No. 40 dengan tujuan untuk mengetahui nilai indeks plastisitas tanah.

\section{Batas Atterberg}

Pengujian Atterberg adalah pengujian yang dilakukan untuk menentukan angka-angka konsistensi atterberg berdasarkan nilai batas cair dan batas plastis.

\section{Kuat Geser Tanah (Direct Shear Test)}

Kuat geser tanah adalah gaya perlawanan yang dilakukan oleh butir-butir tanah terhadap desakan atau tarikan. 
JURNAL KACAPURI

JURNAL KEILMUAN TEKNIK SIPIL

Volume 4 Nomor 2 Edisi Desember 2021

\section{Kuat Geser Tanah Langsung (Direct Shear Test)}

Pengujian geser langsung merupakan salah satu jenis pengujian tertua dan sangat sederhana untuk menentukan parameter kuat geser tanah (shear strength parameter) yaitu : kohesi (c) dan sudut geser dalam ( $\phi)$.

\section{Daya Dukung Tanah}

Daya dukung tanah adalah kemampuan tanah untuk memikul tekanan atau beban maksimum yang diizinkan untuk bekerja pada pondasi.

\section{METODE PENELITIAN}

\section{Lokasi Penelitian}

Lokasi penelitian adalah tempat dimana penelitian dilakukan. Penelitian ini dilakukan di Kel. Petuk Katimpun KM.10 Kec. Jekan Raya Kota Palangka Raya, Provinsi Kalimantan Tengah.

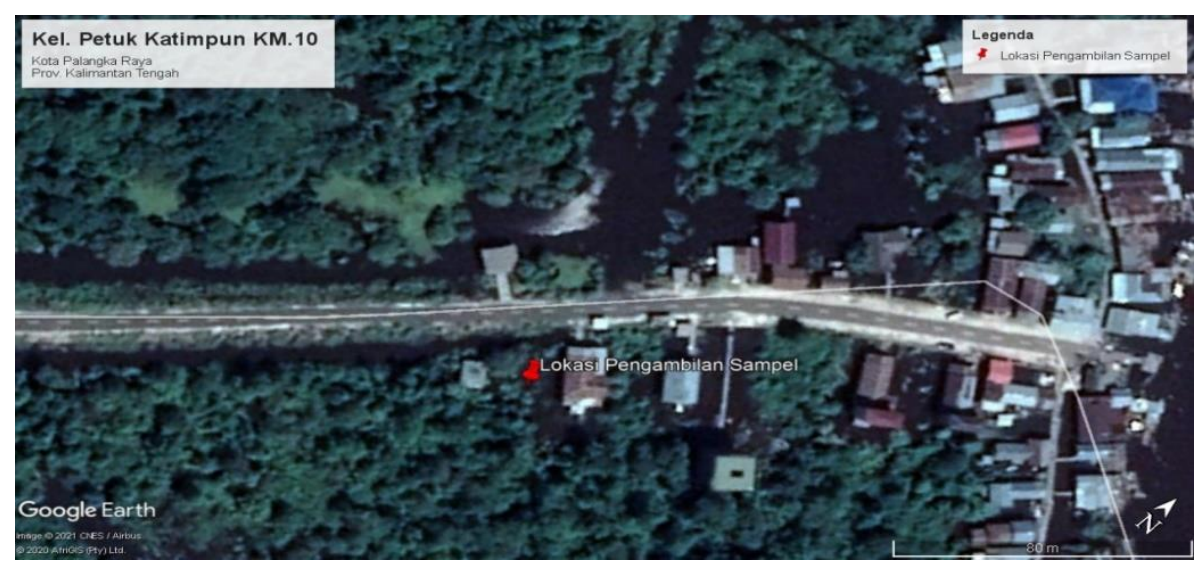

Sumber : Google Earth

Gambar 1. Peta Lokasi Pengambilan Sampel Kel. Petuk Katimpun KM.10

\section{Metode Pengambilan Data}

Pengumpulan data sifat fisik yang dilakukan menggunakan teknik pengambilan sampel secara sengaja, dimulai dari survei lokasi, penentuan lokasi untuk pengambilan sampel tanah.

\section{Pengambilan Sampel}

Sampel tanah yang diambil adalah tanah tidak terganggu (undisturbed soil). Sampel tanah tidak terganggu adalah sampel tanah yang masih alami dan tidak terganggu oleh lingkungan luar. Sampel tanah diambil setelah dilakukan pengamatan dan survei lokasi.

\section{Pengujian Laboratorium}

\section{Pemeriksaan Sifat Fisik Tanah}

\section{Pengujian Kadar Air}

Pengujian kadar air dilakukan dengan menggunakan standar ASTM D-2216, AASHTO T-265-79

\section{Pengujian Analisis Saringan}

Pengujian ini dilakukan dengan menggunakan standar ASTM C-136-46, AASHTO T27-74 


\section{Pengujian Batas Atterberg}

a. Batas cair Pengujian ini menggunakan standar AASHTO T-89-74, ASTM D-423-66

b. Batas plastis

Pengujian ini menggunakan standar ASTM D-424-74, AASTHO T-90-74

c. Batas Susut

Pengujian ini menggunakan standar AASHTO T-92-68

\section{Pemeriksaan Sifat Mekanik Tanah}

Pengujian Kuat Geser Langsung (Direct Shear Test)

Pengujian ini dilakukan dengan menggunakan pengujian standar proctor yang mengacu pada standar AASHTO T-236-N-72, ASTM D-3080-72.

\section{Perencanaan Campuran}

Campuran direncanakan berdasarkan metode coba-coba (trial and error) yaitu tanah lempung dicampur dengan air dengan presentase penambahan air sebesar 5\%,10\%, $15 \%$ dari berat tanah. Benda uji ini akan diperam dengan lama waktu pemeraman 1 hari.

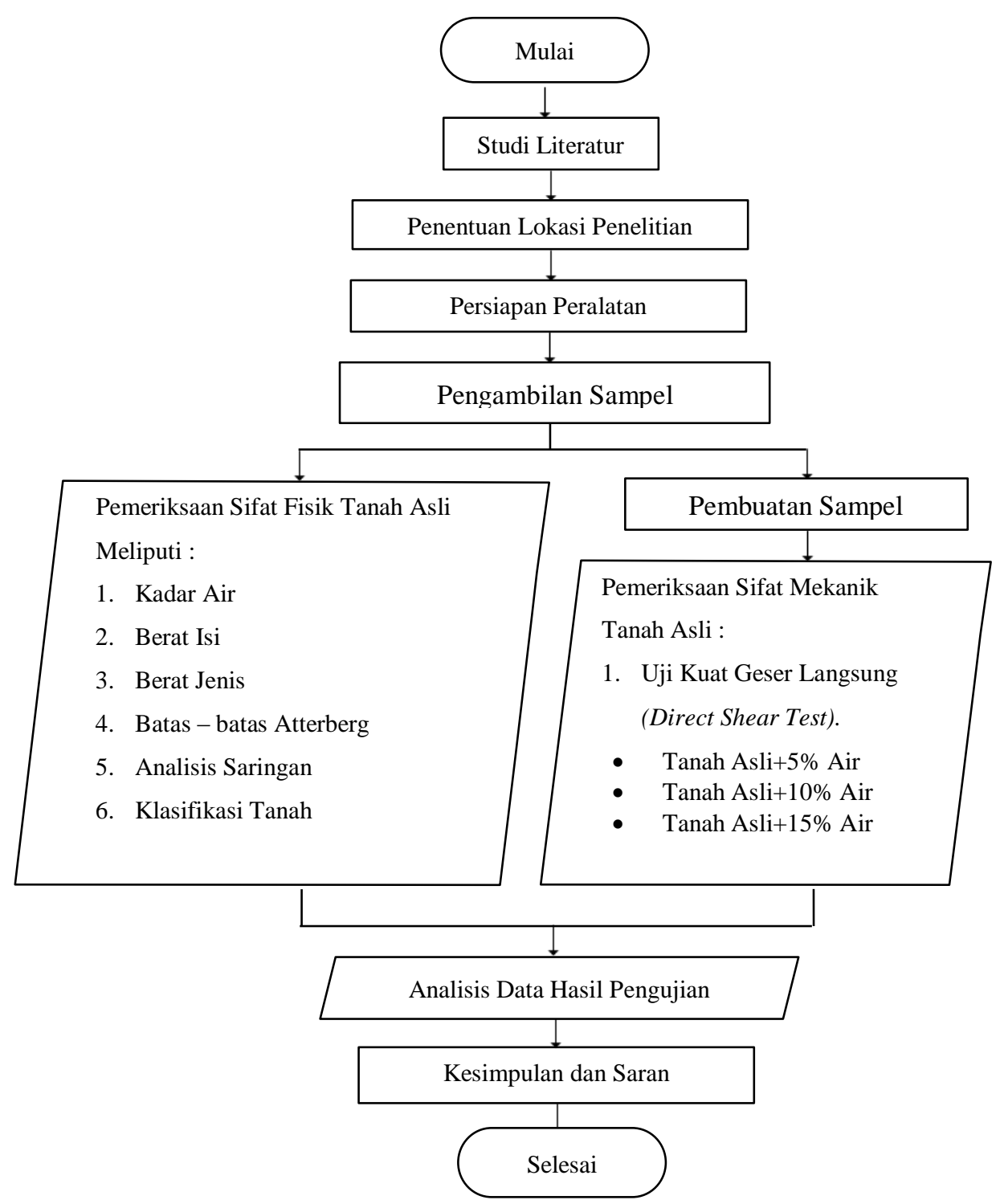

Gambar 2. Bagan Alir Penelitian 


\section{HASIL PENELITIAN DAN PEMBAHASAN}

\section{Hasil Pengujian Sifat-Sifat Fisik Tanah}

Tabel 1. Hasil Pemeriksaan Sifat Fisik Tanah Pada Jenis Tanah Lempung

\begin{tabular}{|c|lc|c|}
\hline No. & \multicolumn{1}{|c|}{ Jenis Pemeriksaan } & Hasil Pengujian Rata-rata \\
\hline 1. & Kadar Air (Water Content) (W) & $\%$ & 33,47 \\
\hline 2. & Berat Isi Tanah Kering $\gamma d$ & & 1,25 \\
\hline 3. & Angka Pori (e) & & 0,87 \\
\hline 3. & Porositas (n) & & 0,42 \\
\hline 4. & Berat Jenis (Specific Gravity) (Gs) & $\%$ & 2,34 \\
\hline 5. & Batas-Batas Atterberg & $\%$ & 31,50 \\
\hline & a. Batas Cair (Liquid Limit) & $\%$ & 17,12 \\
\hline & b. Batas Plastis (Plastic Limit) & 14,38 \\
\hline & c. Indeks Plastis (Plastic Indeks) & $\%$ & 14,41 \\
\hline & d. Batas Susut (Shrinkage Limit) & $\%$ & \\
\hline 6. & Analisa Saringan & & 48,57 \\
\hline & a. Persentase Tertahan No.200 & & 51,43 \\
\hline & b. Persentase Lolos No.200 & & 1,25 \\
\hline 7. & Analisis Hydrometer & & \\
\hline
\end{tabular}

Sumber : Hasil Penelitian, (2021)

Berdasarkan data hasil pengujian Tabel 1 dapat dilihat bahwa tanah Kel. Petuk Katimpun KM.10 termasuk kedalam tanah berbutir halus dengan nilai 51,43\% atau lebih dari $50 \%$.

\section{Analisis Atterberg}

\section{Batas Cair (Liquid Limit)}

Batas cair didefinisikan sebagai nilai kadar air tanah pada batas antara keadaan cair dan plastis atau pada ketukan ke 25. Adapun nilai batas plastis dapat dilihat pada grafik berikut:

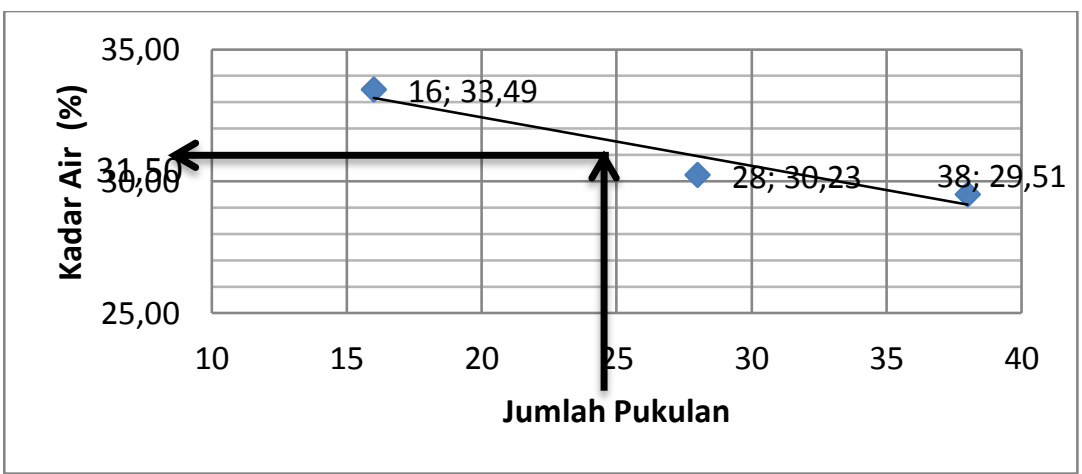

Gambar 3. Grafik Pengujian Batas Cair 
Dari grafik dalam gambar 3 dapat dilihat bahwa nilai batas cair atau liquid limit (nilai kadar air pada jumlah ketukan sebanyak 25 kali) adalah 31,50\%

\section{Batas Plastis (Plastic Limit)}

Batas plastis adalah nilai kadar air suatu tanah pada batas bawah daerah plastisnya. Nilai batas plastis sampel tanah didapatkan yaitu $17,12 \%$.

\section{Indeks Plastisitas (Plasticity Index)}

Indeks plastisitas merupakan nilai selisih antara batas plastis dan batas cair. Berdasarkan nilai batas cair (liquid limit) dan batas plastis (plastic limit) didapatkan nilai indeks plastisitas sebesar $14,38 \%$.

\section{Analisis Metode Klasifikasi Tanah}

\section{Metode Klasifikasi AASHTO}

Berdasarkan data analisis saringan Tabel 1. didapatkan nilai persentase lolos saringan No. 200 sebesar 51,43\% atau lebih dari 35\% dengan lolos ayakan No. 40 memiliki nilai batas cair $31,50 \%$ dan indeks plastisitas $14,38 \%$ maka tanah tersebut termasuk dalam klasifikasi lanau-lempung (silt clay) kelompok A-6.

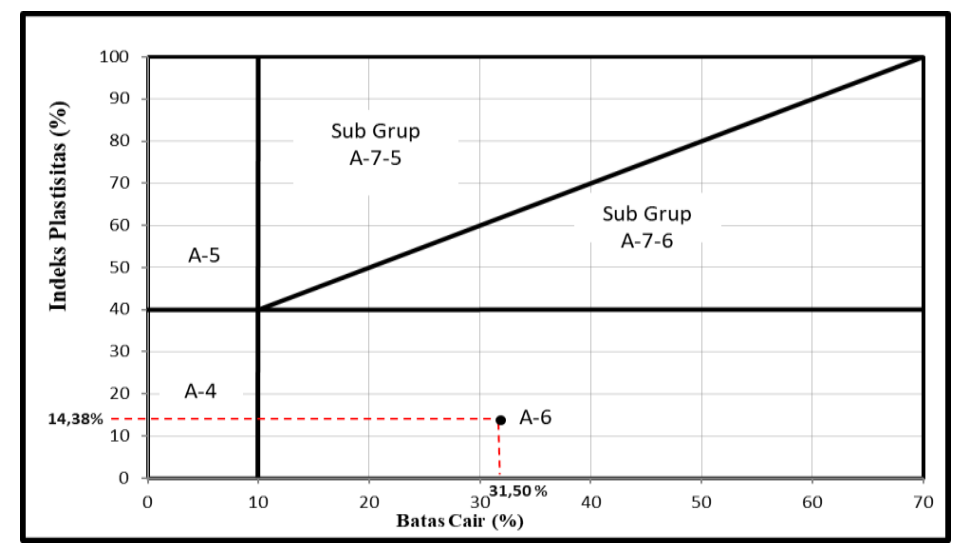

Gambar 4. Grafik Klasifikasi Tanah Sistem Klasifikasi AASHTO

\section{Metode Klasifikasi USCS}

Dalam mengklasifikasikan kadar butiran halus yang terkandung dalam tanah menurut metode USCS digunakan grafik diagram klasifikasi. Dengan nilai indeks plastisitas 14,38\% dan batas cair 31,50\% maka didapatkan grafik seperti pada Gambar 3.

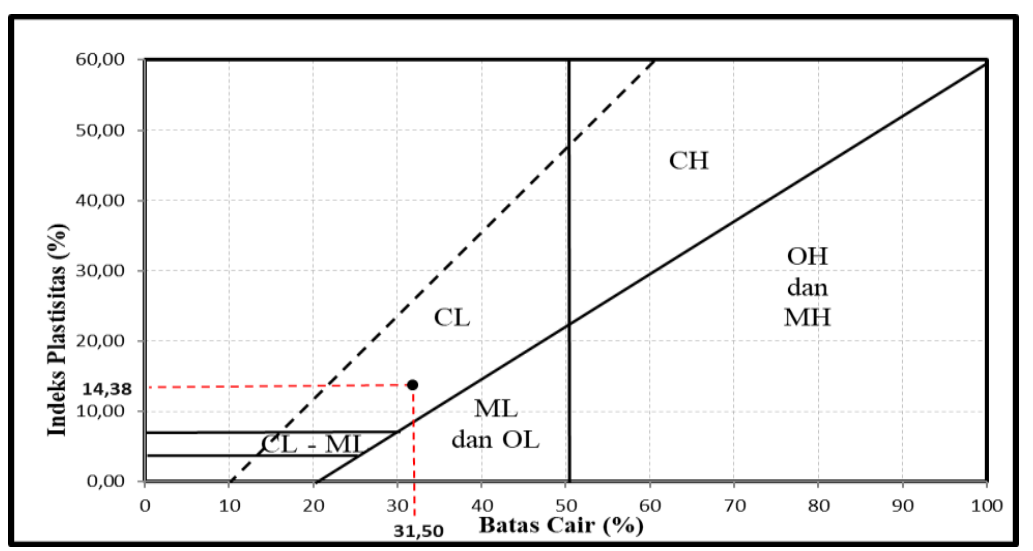

Gambar 5. Grafik Klasifikasi Tanah Sistem Klasifikasi USCS 
Dari grafik dalam gambar 5. dapat dilihat bahwa sampel tanah adalah tanah lempung anorganik dengan plastisitas rendah sampai dengan sedang yaitu lempung berkerikil, lempung berpasir, lempung berlanau, lempung "kurus" kelompok CL.

\section{Hasil Pengujian Sifat-Sifat Mekanik Tanah}

\section{Kuat Geser Langsung}

a. Kuat Geser Pada Tanah Asli

Berdasarkan hasil pemeriksaan uji geser langsung di laboratorium diperoleh grafik tegangan (sumbu Y) dan regangan (sumbu X) untuk menentukan nilai kohesi dan sudut geser tanah. Dapat dilihat pada grafik berikut :

Tabel 2. Hasil Pemeriksaan Uji Kuat Geser Langsung Pada Tanah asli

\begin{tabular}{|c|c|c|c|c|c|c|c|c|c|c|}
\hline \multicolumn{2}{|c|}{ Gaya Normal } & \multicolumn{3}{|c|}{$\mathrm{Pl}=3,167 \mathrm{~kg}$} & \multicolumn{3}{|c|}{$\mathrm{P} 2=6,334 \mathrm{~kg}$} & \multicolumn{3}{|c|}{$\mathrm{P} 3=12,668 \mathrm{~kg}$} \\
\hline \multicolumn{2}{|c|}{ Teg. Normal } & \multicolumn{3}{|c|}{$\sigma \mathrm{l}=0,1 \mathrm{~kg} / \mathrm{cm}^{2}$} & \multicolumn{3}{|c|}{$\sigma 2=0,2 \mathrm{~kg} / \mathrm{cm}^{2}$} & \multicolumn{3}{|c|}{$03=0,4 \mathrm{~kg} / \mathrm{cm}^{2}$} \\
\hline Waktu & Pergeseran & Dial & Gaya & Teg. & Dial & Gaya & Teg. & Dial & Gaya & Teg. \\
\hline (minute) & & Reading & Geser & 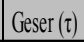 & Reading & Geser & $\operatorname{Geser}(\tau)$ & Reading & Geser & $\operatorname{Geser}(\tau)$ \\
\hline 0 & 20 & 9,0 & 4,520 & 0,121 & 10,1 & 5,072 & 0,136 & 11,5 & 5,775 & 0,155 \\
\hline $1 / 4$ & 40 & 10,5 & 5,273 & 0,142 & 10,8 & 5,424 & 0,146 & 12,9 & 6,478 & 0,174 \\
\hline 12 & 60 & 12,2 & 6,127 & 0,165 & 11,2 & 5,625 & 0,151 & 13,5 & 6,780 & 0,182 \\
\hline 1 & 80 & 13,1 & 6,579 & 0,177 & 12,3 & 6,177 & 0,166 & 14,1 & 7,081 & 0,190 \\
\hline 1,5 & 100 & 13,9 & 6,981 & 0,188 & 12,9 & 6,478 & 0,174 & 14,8 & 7,433 & 0,200 \\
\hline 2 & 120 & 14,4 & 7,232 & 0,194 & 13,7 & 6,880 & 0,185 & 15,3 & 7,684 & 0,206 \\
\hline 2,5 & 140 & 15,8 & 7,935 & 0,213 & 14,6 & 7,332 & 0,197 & 15,9 & 7,985 & 0,215 \\
\hline 3 & 160 & 17,7 & 8,889 & 0,239 & 15,1 & 7,583 & 0,204 & 16,7 & 8,387 & 0,225 \\
\hline 3,5 & 180 & 18,1 & 9,090 & 0,244 & 15,8 & 7,935 & 0,213 & 17,0 & 8,537 & 0,229 \\
\hline 4 & 200 & 17,9 & 8,989 & 0,242 & 16,1 & 8,085 & 0,217 & 18,1 & 9,090 & 0,244 \\
\hline 4,5 & 220 & - & - & - & 16,7 & 8,387 & 0,225 & 19,2 & 9,642 & 0,259 \\
\hline 5 & 240 & - & - & - & 18,5 & 9,291 & 0,250 & 19,9 & 9,994 & 0,269 \\
\hline 6 & 260 & - & - & - & 19,1 & 9,592 & 0,258 & 21,4 & 10,747 & 0,289 \\
\hline 7 & 280 & - & - & - & 20,7 & 10,396 & 0,279 & 22,6 & 11,350 & 0,305 \\
\hline 8 & 300 & - & - & - & 20,1 & 10,094 & 0,271 & 23,1 & 11,601 & 0,312 \\
\hline 9 & 320 & - & - & - & - & - & - & 25,7 & 12,907 & 0,347 \\
\hline 10 & 340 & - & - & - & - & - & - & 26,5 & 13,308 & 0,358 \\
\hline 11 & 360 & - & - & . & - & - & - & 26,2 & 13,158 & 0,354 \\
\hline
\end{tabular}

Sumber : Hasil Penelitian, (2021)

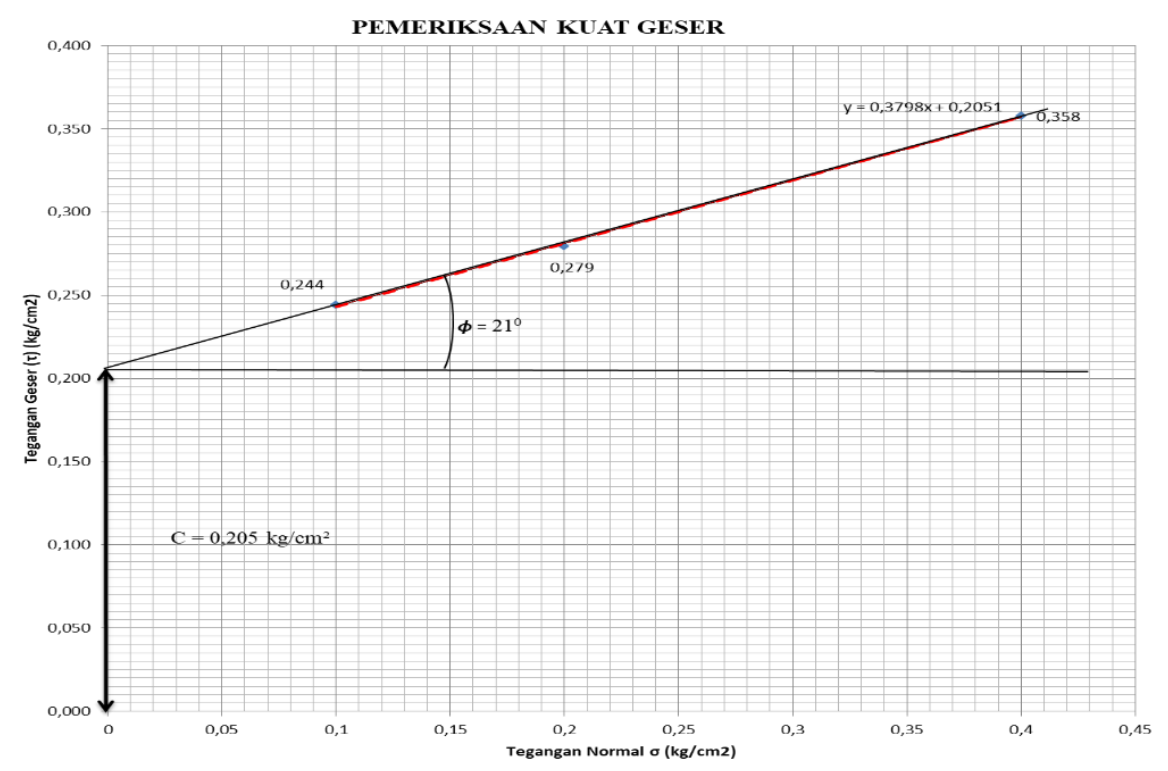


Sumber : Hasil Penelitian, (2021)

Gambar 4. Grafik Uji Geser Langsung Pada Tanah Asli + 5\% Air

Dilihat dari pembacaan gambar 4.3 grafik uji geser langsung (Direct Shear Test) didapatkan nilai kohesi tanah (c) sebesar $0,205 \mathrm{Kg} / \mathrm{cm}^{2}$ dan sudut geser tanah (Ø) sebesar $21^{0}$.

$$
\begin{aligned}
\text { Tegangan Normal } \sigma & =\gamma \cdot \mathrm{h} \\
& =1,25 \mathrm{gr} / \mathrm{cm}^{3} \times 100 \mathrm{~cm} \\
& =125 \mathrm{gr} / \mathrm{cm}^{3} \\
& =0,125 \mathrm{~kg} / \mathrm{cm}^{2} \\
\text { Jadi tegangan geser tanah }(\tau) & =\mathrm{c}+\sigma \tan \emptyset \\
& =0,205+0,125 \times \tan \left(19^{0}\right) \\
& =0,253 \mathrm{~kg} / \mathrm{cm}^{2}
\end{aligned}
$$

\begin{tabular}{|c|c|c|c|}
\hline \multirow{3}{*}{ Sampel } & Kohesi & \multirow{2}{*}{$\begin{array}{c}\text { Sudut Geser } \\
\text { Tanah }(\varnothing)\end{array}$} & Tegangan geser \\
\hline & (C) & & $(\tau)$ \\
\hline & $\mathrm{Kg} / \mathrm{cm} 2$ & $\left({ }^{\circ}\right)$ & $\mathrm{Kg} / \mathrm{cm} 2$ \\
\hline \multicolumn{4}{|l|}{ 0 Hari ( Tanpa Pemeraman ) } \\
\hline Tanah Asli & 0,205 & $21^{\circ}$ & 0,253 \\
\hline Tanah Asli Dikeringkan 2 Jam & 0,216 & $22^{\circ}$ & 0,267 \\
\hline Tanah Asli Dikeringkan 4 Jam & 0,228 & $23^{\circ}$ & 0,281 \\
\hline Tanah Asli Dikeringkan 6 Jam & 0,230 & $25^{\circ}$ & 0,288 \\
\hline \multicolumn{4}{|l|}{1 Hari ( Pemeraman ) } \\
\hline Tanah Asli + Air 5\% & 0,155 & $19^{\circ}$ & 0,198 \\
\hline Tanah Asli + Air $10 \%$ & 0,125 & $18^{\circ}$ & 0,166 \\
\hline Tanah Asli + Air $15 \%$ & 0,090 & $16^{\circ}$ & 0,126 \\
\hline
\end{tabular}

\begin{tabular}{|c|c|c|}
\hline \multirow{2}{*}{ Sampel } & Tegangan Geser $(\tau)$ & Kadar Air \\
\hline & $(\mathrm{kg} / \mathrm{cm} 2)$ & $(\%)$ \\
\hline \multicolumn{3}{|l|}{ o Hari Pemeraman } \\
\hline Tanah Asli & 0,253 & 33,23 \\
\hline Tanah Yang Dikeringkan 2 Jam & 0,267 & 10,96 \\
\hline Tanah Yang Dikeringkan 4 Jam & 0,281 & 7,66 \\
\hline Tanah Yang Dikeringkan 6 Jam & 0,288 & 5,64 \\
\hline \multicolumn{3}{|l|}{1 Hari Pemeraman } \\
\hline Tanah + Campuran Air 5\% & 0,198 & 44,17 \\
\hline Tanah + Campuran Air $10 \%$ & 0,166 & 58,36 \\
\hline Tanah + Campuran Air $15 \%$ & 0,126 & 69,38 \\
\hline
\end{tabular}

Dari hasil hitungan di atas didapatkan :

Tabel 3. Rekapitulasi Pengujian Kuat Geser Langsung (Direct Shear)

Sumber : Hasil Penelitian, (2021)

Tabel 4. Rekapitulasi Pengujian Kuat Geser Langsung 


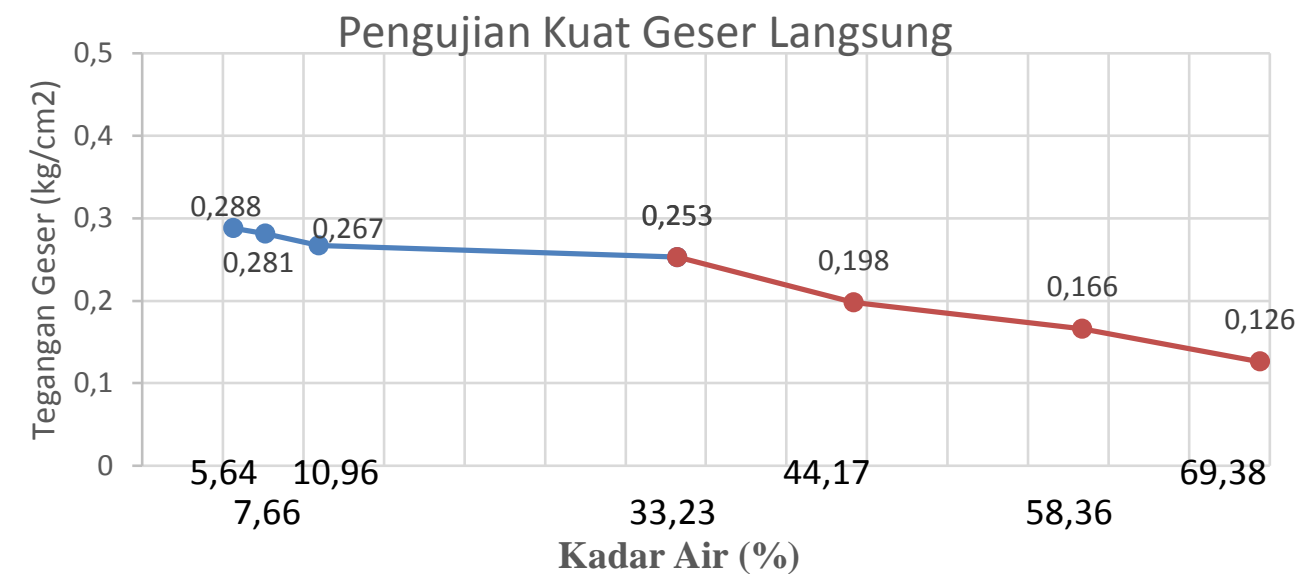

Gambar 5. Grafik hubungan nilai tegangan geser dan kadar air

Tabel 5. Rekapitulasi Pengujian Kuat Geser (Kohesi)

\begin{tabular}{|c|c|c|}
\hline \multirow{2}{*}{ Sampel } & Kohesi (C) & Kadar Air \\
\hline & $\mathrm{kg} / \mathrm{cm} 2$ & $(\%)$ \\
\hline \multicolumn{3}{|l|}{ o Hari Pemeraman } \\
\hline Tanah Asli & 0,205 & 33,23 \\
\hline Tanah Yang Dikeringkan 2 Jam & 0,216 & 10,96 \\
\hline Tanah Yang Dikeringkan 4 Jam & 0,228 & 7,66 \\
\hline Tanah Yang Dikeringkan 6 Jam & 0,230 & 5,64 \\
\hline \multicolumn{3}{|l|}{1 Hari Pemeraman } \\
\hline Tanah + Campuran Air 5\% & 0,150 & 44,17 \\
\hline Tanah + Campuran Air $10 \%$ & 0,125 & 58,36 \\
\hline Tanah + Campuran Air $15 \%$ & 0,090 & 69,38 \\
\hline
\end{tabular}

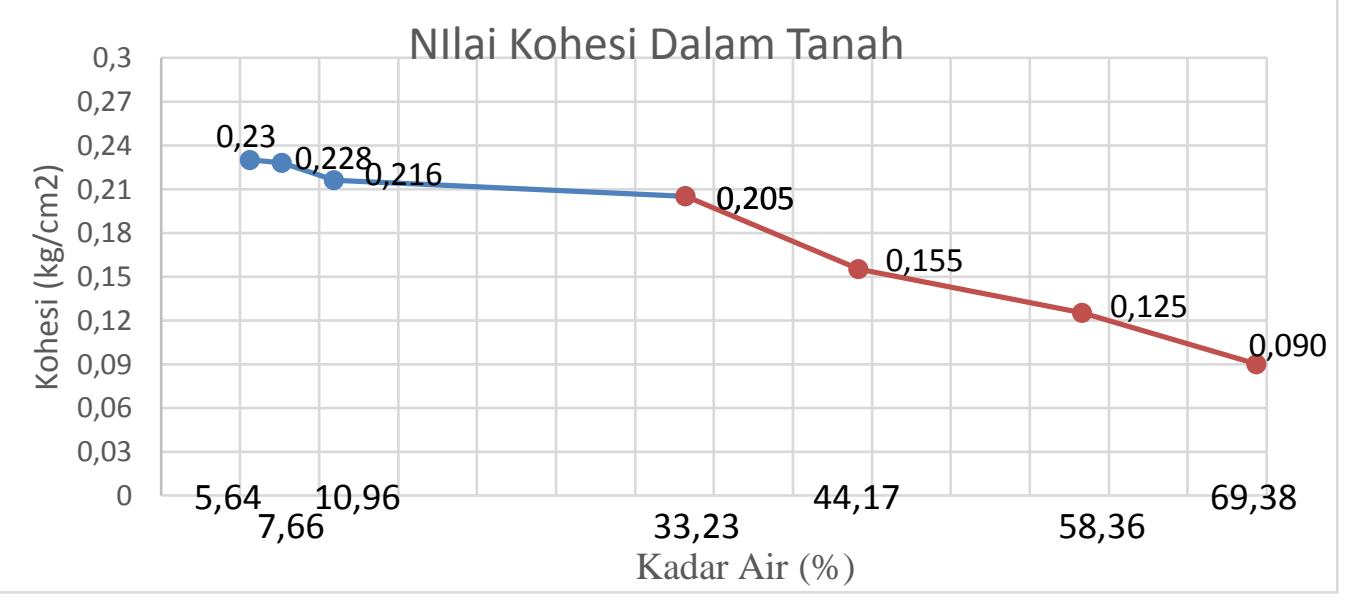

Gambar 6. Grafik hubungan nilai kohesi dan kadar air

\section{Perhitungan Daya Dukung Tanah Menurut Terzaghi (1943)}

$$
\begin{array}{ll}
\mathrm{Nc}=18,7 & \mathrm{DF}=100 \mathrm{~cm} \\
\mathrm{Nq}=8,0 & \mathrm{~B}=100 \mathrm{~cm}
\end{array}
$$




$$
\begin{aligned}
\mathrm{N}_{\gamma}=6,0 \quad \gamma & =0,125 \mathrm{gr} / \mathrm{cm}^{3} \\
& =0,00125 \mathrm{~kg} / \mathrm{cm}^{2}
\end{aligned}
$$

Keruntuhan Geser Umum :

$$
\begin{aligned}
\mathrm{qult}_{\mathrm{ult}} & =\mathrm{c} \cdot \mathrm{Nc}+\mathrm{DF} \cdot \gamma \cdot \mathrm{Nq}+0,5 \cdot \gamma \cdot \mathrm{B} \cdot \mathrm{N}_{\gamma} \\
= & (0,205 \times 18,7)+(100 \times 0,00125 \times 8,0)+(0,5 \times 0,00125 \times 100 \\
& \quad \mathrm{x} 6,0) \\
= & 5,17 \mathrm{~kg} / \mathrm{cm}^{2}
\end{aligned}
$$

\begin{tabular}{|c|c|c|c|c|c|}
\hline \multirow{3}{*}{ Kondisi Contoh Tanah } & \multirow{2}{*}{$\begin{array}{c}\text { Sudut Geser } \\
\text { Tanah }(\emptyset)\end{array}$} & \multirow{2}{*}{$\begin{array}{c}\text { Kohesi } \\
\text { (C) }\end{array}$} & \multirow{2}{*}{ Kadar Air } & \multicolumn{2}{|c|}{ Daya Dukung Tanah Lempung } \\
\hline & & & & qult & qijin \\
\hline & $\left({ }^{0}\right)$ & $\mathrm{Kg} / \mathrm{cm} 2$ & $(\%)$ & $(\mathrm{kg} / \mathrm{cm} 2)$ & $(\mathrm{kg} / \mathrm{cm} 2)$ \\
\hline \multicolumn{6}{|l|}{0 Hari ( Tanpa Pemeraman) } \\
\hline Tanah Asli & $21^{\circ}$ & 0,205 & 33,23 & 5,17 & 1,72 \\
\hline Tanah Asli Dikeringkan 2 Jam & $22^{\circ}$ & 0,216 & 10,96 & 5,69 & 1,90 \\
\hline Tanah Asli Dikeringkan 4 Jam & $23^{\circ}$ & 0,228 & 7,66 & 6,25 & 2,08 \\
\hline Tanah Asli Dikeringkan 6 Jam & $25^{\circ}$ & 0,23 & 5,64 & 6,94 & 2,31 \\
\hline \multicolumn{6}{|l|}{1 Hari ( Pemeraman $)$} \\
\hline Tanah Asli + Air 5\% & $19^{\circ}$ & 0,155 & 44,17 & 3,64 & 1,21 \\
\hline Tanah Asli + Air $10 \%$ & $18^{\circ}$ & 0,125 & 58,36 & 3,00 & 1,00 \\
\hline Tanah Asli + Air $15 \%$ & $16^{\circ}$ & 0,090 & 69,38 & 2,06 & 0,69 \\
\hline
\end{tabular}

Daya dukung ijin tanah yang berdasarkan nilai faktor keamanan

$=3$, jadi didapat nilai $\mathrm{q}_{\mathrm{ijin}}$ :

$$
\begin{aligned}
\mathrm{q}_{\mathrm{ijin}} & =\left(\frac{1}{S F}\right) \times \mathrm{q}_{\mathrm{ult}} \\
& =\left(\frac{1}{3}\right) \times 5,20 \\
& =1,72 \mathrm{~kg} / \mathrm{cm}^{2}
\end{aligned}
$$

Dari Perhitungan diatas didapatkan Tabel 5.

Sumber : Hasil Penelitian, (2021)

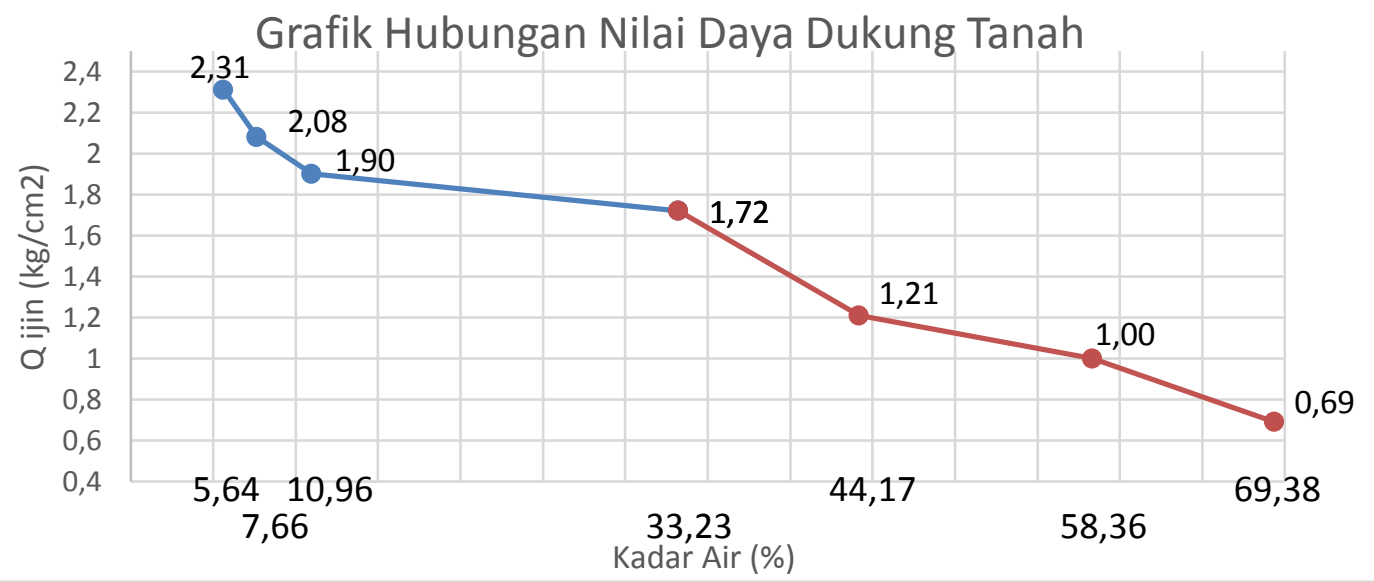

Gambar 8. Grafik hubungan nilai daya dukung tanah dan kadar air

\section{KESIMPULAN DAN SARAN}

\section{Kesimpulan}

Berdasarkan hasil penelitian yang telah dilakukan, untuk mengetahui sifat fisik dan mekanik tanah lempung pada Kel. Petuk Katimpun KM.10 Kec. Jekan Raya, Kota 
Palangka Raya, maka dapat diambil kesimpulan sebagai berikut :

1. Dari hasil pengujian geser langsung (Direct Shear) terhadap nilai kuat geser dan daya dukung tanah asli yang dikeringkan 6 jam didapat nilai kuat geser $(\tau)$ tertinggi $0,288 \mathrm{~kg} / \mathrm{cm}^{2}$, sudut geser $25^{\circ}$, kohesi (c) $0,230 \mathrm{~kg} / \mathrm{cm}^{2}$, dengan persentase sebesar $13,83 \%$ sedangkan untuk nilai daya dukung tanah didapat nilai $\mathrm{q}_{\text {ult }}=6,94 \mathrm{~kg} / \mathrm{cm}^{2}$, dan nilai $\mathrm{q}_{\mathrm{ijin}}=2,31 \mathrm{~kg} / \mathrm{cm}^{2}$. Setelah penambahan pada campuran tanah asli $+5 \%$ air didapat nilai kuat geser $(\tau)$ sebesar $0,198 \mathrm{~kg} / \mathrm{cm}^{2}$, sudut geser $19^{\circ}$, kohesi (c) $0,150 \mathrm{~kg} / \mathrm{cm}^{2}$ sedangkan untuk nilai daya dukung tanah didapat nilai $\mathrm{q}_{\text {ult }}=3,64 \mathrm{~kg} / \mathrm{cm}^{2}$, dan nilai $\mathrm{q}_{\mathrm{ijin}}=1,21 \mathrm{~kg} / \mathrm{cm}^{2}$. Sehingga dengan penambahan air memberikan pengaruh terhadap nilai kuat geser dan daya dukung pada tanah lempung.

\section{Saran}

Berdasarkan hasil dari penelitian dan analisis data yang dilakukan, maka disarankan halhal sebagai berikut :

1. Saran terhadap penelitian ini adalah untuk mengetahui efektif atau tidaknya campuran air, perlu diteliti lebih lanjut sehingga nilai nyata terjadinya perubahan akibat pengaruh penambahan bahan tersebut.

2. Terjadinya penurunan sudut geser, sebaiknya dilakukan dengan kombinasi campuran lain.

3. Pengawasan intensif perlu dilakukan pada pelaksanaan pembuatan sampel di laboratorium dan juga perlu diperhatikan kondisi peralatan yang digunakan pada saat penelitian.

\section{DAFTAR PUSTAKA}

Bowles, J E. 1984, Sifat-Sifat Fisis dan Geoteknis Tanah (Mekanika Tanah), Edisi Kedua, Erlangga, Jakarta.

Bowles, J E. 1991. Sifat-sifat Fisis Tanah dan Geoteknis Tanah. Erlangga. Jakarta

Das, Braja M. 1985. Mekanika Tanah (Jilid 1) Terjemahan. Jakarta: Erlangga

Hardiyatmo, Hary Christady. 1992, Mekanika Tanah 1, PT. Gramedia Pustaka Utama, Jakarta.

Hary Christady, 1996. Sistem Clasifikasi Unified Soil Clasification System (USCS)

Herman 2018, Pengaruh Penambahan Abu Limbah Kertas Terhadap Kembang Susut Tanah Lempung, Tugas akhir Mahasiswa Program Studi Teknik Sipil S1, Fakultas Teknik Sipil dan Perencanaan Institut Teknologi Padang

Ika Meisy Putri Rahmawati, 2015, Pengaruh Kadar Air Terhadap Kuat Geser Tanah Ekspansif Bojonegoro Dengan Stabilisasi Menggunakan 15\% Fly Ash Dengan Metode Deep Soil Mix, Malang.

Terzaghi, Karl and Peck, B Ralph,1967, "Soil Mechanics in Engineering Practice, Second Edition", New York. 